\title{
The importance of public health in managing health care costs in the United Kingdom National Health Service
}

This article was published in the following Dove Press journal:

Risk Management and Healthcare Policy

27 September 2016

Number of times this article has been viewed

\author{
Meelad Sayma \\ Tomos Luke Treharne \\ Hywel Rhys Williams \\ Peninsula College of Medicine and \\ Dentistry, UK
}

Correspondence: Meelad Sayma

Knowledge Spa, Royal Cornwall Hospital

Trust, Treliske, Truro, TRI 3HD, UK

Emailmeeladsayma@yahoo.co.uk

\section{Dear editor}

McPhail's review tackles the problem of our generation in the developed world - the ageing population increasing the proportion of patients with multiple comorbidities. ${ }^{1}$ Combined with chronic underfunding, this problem has had, and will continue to have a huge financial burden on the United Kingdom's National Health Service (UK NHS) ${ }^{2,3}$ In recent years, a pattern of regular crippling winter "crisis" in NHS hospitals has emerged, with some questioning the sustainability of a "free at the point of access" service. 4,5

McPhail highlights the importance of prioritizing research in health system approaches to combat this burden. We wholeheartedly agree with this point, and believe the development of new health care systems is crucial to the survival of the NHS. This need is currently reflected in pilot "vanguard" schemes being utilized in England to fast-track health system and service innovation. ${ }^{6}$ However, the focus on health care systems, and in particular service innovation, may not be enough to sustain the UK NHS.

Modifiable risk factors appear to be at the root cause of many of the most prevalent and costly comorbidities in the UK, most importantly in obesity, smoking, and alcohol consumption. ${ }^{3}$ As a result, innovation in preventing such conditions is hugely important to the sustainability of the NHS as we know it. Public health approaches to reducing smoking prevalence have shown mixed results, with efforts to curb obesity through reduced sugar consumption suffering from suboptimal levels of investment. ${ }^{7,8}$

It is imperative to not only further invest in public health approaches to prevent highly prevalent risk factors, but to also foster innovation in these approaches to ensure effective use of these financial resources. This innovation may come from a multitude of sources. One option is to utilize marketing techniques already used in the unhealthy food industries to promote healthier options. ${ }^{8}$ While another option could be to alter policy and regulations to modify food and alcohol consumption patterns. ${ }^{8}$

In conclusion, public health approaches have the potential to save a large amount of downstream financial resources in the NHS - however there has to be a focus on both adequate investment and effective use of public health techniques.

\section{Disclosure}

The authors report no conflicts of interest in this communication. 


\section{References}

1. McPhail SM. Multimorbidity in chronic disease: impact on health care resources and costs. Risk Manag Healthc Policy. 2016; 9:143-156.

2. Rudisill C, Charlton J, Booth HP, Gulliford MC. Are healthcare costs from obesity associated with body mass index, comorbidity or depression? Cohort study using electronic health records. Clin Obes. 2016;6(3):225-231.

3. Scarborough P, Bhatnagar P, Wickramasinghe KK, Allender S, Foster $\mathrm{C}$, Rayner M. The economic burden of ill health due to diet, physical inactivity, smoking, alcohol and obesity in the UK: an update to 2006-07 NHS costs. J Public Health (Oxf). 2011;33(4):527-535.

4. Filochowski J. A SUSTAINABLE HEALTH SERVICE. Why the NHS is facing a crisis again this winter. Health Serv J. 2016;125(6472):16-17.
5. Pencheon D. Making health care more sustainable: the case of the English NHS. Public Health. 2015;129(10):1335-1343.

6. NHS England. NEWCARE MODELS: Vanguards - developing a blueprint for the future of NHS and care services. 2016. Available from: https://www. england.nhs.uk/wp-content/uploads/2015/11/new_care_models.pdf.

7. Lewis S, Sims M, Richardson S, et al. The effectiveness of tobacco control television advertisements in increasing the prevalence of smoke-free homes. BMC Public Health. 2015;15:869.

8. Public Health England. Sugar Reduction: The evidence for action. 2015. Available from: https:/www.gov.uk/government/uploads/system/ uploads/attachment_data/file/470179/Sugar_reduction_The_evidence_ for_action.pdf. 


\section{Author's reply \\ Steven M McPhail ${ }^{1,2}$}

'Centre for Functioning and Health Research, Metro South Health, ${ }^{2}$ Institute of Health and Biomedical Innovation and School of Public Health and Social Work, Queensland University of Technology, Brisbane, QLD, Australia

Correspondence: Steven M McPhail

Centre for Functioning and Health Research, Corner of Ipswich Road and Cornwall Street, Buranda, Brisbane, QLD, Australia

Tel +6I 734062266

Fax +6I 734062267

Email steven.mcphail@qut.edu.au

\section{Dear editor}

Sayma et al have advocated for innovation and investment in public health initiatives with specific reference to reducing future demand for services provided by the United Kingdom National Health Service. There are two brief points I would like to proffer in response as further stimulus for consideration by the readership. First, I unreservedly agree with Sayma et al's sentiments that public health innovations have potential to reduce future health service demand where the prevalence of modifiable chronic disease risk factors can be favorably impacted in a sustainable way; indeed I suspect few would disagree with these sentiments.

Second, not all investment in new public health innovations will yield a consistent (or perhaps even observable) return in health benefits and reduced demand for health services. Therefore, I would like to again highlight the importance of appropriate evaluation of not only the shortterm effectiveness of public health innovations in influencing modifiable risk factors, but also consideration of the sustainability of effect and cost-effectiveness of innovative public health interventions or policies. ${ }^{1}$ The judicious allocation of finite public resources in any field of health can be challenging and the allocation of resources to the most cost-effective public health innovations ought to be influenced by appropriate information to guide policy and practice.

\section{Disclosure}

The author reports no conflicts of interest in this communication.

\section{Reference}

1. McPhail S. Multimorbidity in chronic disease: impact on health care resources and costs. Risk Manag Healthc Policy. 2016;9:143-156.

Dove Medical Press encourages responsible, free and frank academic debate. The content of the Risk Management and Healthcare Policy 'letters to the editor' section does not necessarily represent the views of Dove Medical Press, its officers, agents, employees, related entities or the Risk Management and Healthcare Policy editors. While all reasonable steps have been taken to confirm the content of each letter, Dove Medical Press accepts no liability in respect of the content of any letter, nor is it responsible for the content and accuracy of any letter to the editor.

\section{Publish your work in this journal}

Risk Management and Healthcare Policy is an international, peer-reviewed, open access journal focusing on all aspects of public health, policy, and preventative measures to promote good health and improve morbidity and mortality in the population. The journal welcomes submitted papers covering original research, basic science, clinical and epidemiological studies, reviews and evaluations, guidelines, expert opinion and commentary, case reports and extended reports. The manuscript management system is completely online and includes a very quick and fair peerreview system, which is all easy to use. Visit http://www.dovepress.com/ testimonials.php to read real quotes from published authors.

Submit your manuscript here: https:/www.dovepress.com/risk-management-and-healthcare-policy-journal 